\title{
Correction: Implantation of Scharioth macula lens in patients with age-related macular degeneration: results of a prospective European multicentre clinical trial
}

Srinivasan S. Implantation of Scharioth macula lens in patients with age-related macular degeneration: results of a prospective European multicentre clinical trial. BMJ Open Ophth 2019;4:e000322. doi: 10.1136/bmjophth-2019-000322.

This article has been corrected since it published Online First. The following co-authors were missing in the published version.

Gabor Scharioth, ${ }^{3}$ Anneliese Riehl, ${ }^{4}$ Ivan V Tanev, ${ }^{5}$ Pavel Rozsival, ${ }^{6}$ Emmanuel Van Acker, ${ }^{7}$ Zoltan Z Nagy, ${ }^{8}$ Florian Balta, ${ }^{9}$ Jana Nekolova, ${ }^{6}$

3 Aurelios Augenzentrum, Recklinghausen, Germany

4 North View Eye Clinic, Kiel, Germany

5 ZRENIE Private Eye Center, Sofia, Bulgaria

6 Department of Ophthalmology, Faculty Hospital of Hradec Králové, Hradec Králové, Czech Rebuplic

7 Saint Joseph Clinic, Lobbes, Belgium

8 Department of Ophthalmology, Semmelweis University, Budapest, Hungary

9 Clinica Retina, Bucharest, Romania

Open access This is an open access article distributed in accordance with the Creative Commons Attribution Non Commercial (CC BY-NC 4.0) license, which permits others to distribute, remix, adapt, build upon this work non-commercially, and license their derivative works on different terms, provided the original work is properly cited, appropriate credit is given, any changes made indicated, and the use is non-commercial. See:http://creativecommons.org/ licenses/by-nc/4.0/

(C) Author(s) (or their employer(s)) 2019. Re-use permitted under CC BY-NC. No commercial re-use. See rights and permissions. Published by BMJ.

BMJ Open Ophth 2019;4:e000322corr1. doi:10.1136/bmjophth-2019-000322corr1

A) Check for updates 